\title{
Identification and isolation of regulatory B cells in mouse and human
}

\author{
Madhvi Menon*, Elizabeth C. Rosser and Claudia Mauri
}

${ }^{*}$ Authors contributed equally

Centre for Rheumatology, Division of Medicine, University College London, 5 University Street, London WC1E 6JF, United Kingdom

Correspondence to: c.mauri@ucl.ac.uk

\section{Abstract}

Regulatory B cells (Bregs) suppress immune response via the provision of IL10. Due to the phenotypic heterogeneity of described Bregs, it is important to have standardized protocols for their isolation and identification. Previous work by our laboratory has shown that the immature B cell populations in the murine spleen and human peripheral blood produce the highest levels of IL-10 on engagement of $\mathrm{CD} 40$, and can suppress pro-inflammatory $\mathrm{T}$ cell differentiation. In this chapter, we describe the methods necessary for the isolation of this subset of Bregs and their activation via CD40 in vitro.

Key words: Regulatory B cells, inflammation, IL-10, T2-MZP B cells, Immature B cells, CD40. 


\section{Introduction}

B cells are classically viewed as positive effectors of immune responses due to their ability to produce antibody and present antigen. However, in recent years it has become evident that certain subsets of B cells negatively regulate immune responses by skewing lymphocyte differentiation in favour of a regulatory phenotype. Immunosuppressive subsets of B cells are collectively known as regulatory $B$ cells (Bregs) [1].

Multiple subsets of Bregs have been described in both mice and humans. For example, in different mouse models of inflammation, Bregs have been identified as $\mathrm{CD} 19^{+} \mathrm{CD} 21^{\mathrm{hi}} \mathrm{CD} 23^{+} \mathrm{CD} 24^{\mathrm{hi}}$ transitional-2 marginal zone precursor (T2-MZP) B cells [2], CD19+CD21 $1^{\text {hi }}$ CD23-CD24hi marginal zone $B$ cells [3], Tim-1+ B cells [4], and CD5+CD1 hi $^{\text {hi }}$ (B10) cells [5]. Similarly in humans, Bregs have been identified as both $C D 19^{+} C D 24^{\text {hi }} C D 38^{\text {hi immature } B}$ cells [6] and $C_{19} 1{ }^{+} \mathrm{CD} 24^{\mathrm{hi}} \mathrm{CD} 27^{+} \mathrm{B}$ cells [7]. Despite this phenotypic heterogeneity, most Breg subsets produce IL-10 in response to engagement of CD40, toll-like receptor agonists and the B cell receptor (BCR) [1]. Thus, it is important to have reliable protocols that allow for the identification of IL-10producing B cell subsets (Bregs) in both mouse and human.

Previous research by our laboratory has shown that in the context of autoimmunity, Bregs are contained within the immature population of B cells found in the murine spleen or human peripheral blood, and that engagement of CD40 is fundamental for their survival and function. In the murine spleen, T2-MZP B cells isolated from mice in remission from arthritis are the highest producers of IL-10 following stimulation with agonistic anti-CD40 in vitro, and 
are the only B cell subset that can suppress arthritis on adoptive transfer [2]. Within human peripheral blood mononuclear cells (PBMCs), CD19+CD24 ${ }^{\text {hi }}$ CD38 ${ }^{\text {hi }} B$ cells produce the highest amount of IL-10 amongst the different B cell subsets on activation of CD40 in vitro, and most importantly suppress effector $T$ cell responses $[6,8]$. Of note, $C D 19+C D 24^{\text {hi }} C D 38^{\text {hi }} B$ cells are both functionally and numerically defective when isolated from patients with autoimmune disease $[6,8]$.

In this chapter, we describe the detailed methods needed for the isolation of CD19+CD21 ${ }^{\text {hi }}{ }^{+} D 23^{+}$CD24 ${ }^{\text {hi }}$ T2-MZP $B$ cells from mice, and CD19 ${ }^{+}$CD24 ${ }^{\text {hi }}$ CD38 ${ }^{\text {hi immature }} B$ cells from human peripheral blood. We also describe how to identify IL-10-producing B cells in these subsets by flow cytometry following CD40 activation in vitro.

\section{Materials}

Prepare all solutions in a sterile hood. Store all reagents at $4^{\circ} \mathrm{C}$ (unless otherwise stated).

\subsection{Materials needed for the identification and isolation of} regulatory $B$ cells in mice

1. C57BL/6 8-12 week old mice (see Note 1).

2. $5 \mathrm{ml}$ syringes.

3. $70 \mu \mathrm{M}$ Cell Strainers.

4. $15 \mathrm{ml}$ and $50 \mathrm{ml}$ Falcon Tubes.

5. Polypropelene FACS tubes. 
6. Supplemented RPMI 1640 (with L-Glutamine and $\mathrm{NaHCO}_{3}$ ): RPMI, $10 \%$ fetal calf serum (FCS), $0.01 \%$ penicillin-streptomycin, and $50 \square \mathrm{M}$ 2-mercaptoethanol.

7. MACS Buffer: $0.5 \%$ FCS, $2 \mathrm{mM}$ EDTA in $1 \mathrm{X}$ PBS.

8. Trypan Blue for cell counts.

9. OPTIONAL STEP: CD43 (Ly-48) microbeads and LD columns for B cell isolation (Milteyi: Used according to manufacturer's instructions).

10. Flourochrome conjugated anti-mouse CD19 (1D3), CD21 (7G6), CD23 (B3B4) and CD24 (M1/69) (see Note 2).

11. DAPI $(0.05 \mu \mathrm{g} / \mathrm{ml}-0.1 \mu \mathrm{g} / \mathrm{ml})$.

12. Sort collection media: 1:1 mixture of MACS Buffer and FCS.

13. Cell sorter.

14. Agonistic anti-CD40 $(10 \mu \mathrm{g} / \mathrm{ml})$.

15. PMA $(50 \mathrm{ng} / \mathrm{ml})$ and lonomycin $(500 \mathrm{ng} / \mathrm{ml})$.

16. Golgi-stop containing Monensin (BD Biosciences, used according to manufacturer's instructions).

17. Flourochrome conjugated anti-mouse IL-10 (JES5-16E3) (see Note 2).

18. Intracellular fixation buffer (eBiosciences).

19. Permeabilisation buffer (eBiosciences).

20. Live/Dead fixable Dead Cell stain kit.

21.FACS Buffer: $0.5 \%$ FCS, $2 \mathrm{mM}$ EDTA in $1 \mathrm{X}$ PBS, $0.01 \% \mathrm{NaN}_{3}$.

22. Flow cytometer.

23. Flowjo Software, or similar flow cytometry platform. 


\subsection{Materials needed for the identification and isolation of regulatory $B$ cells in humans}

1. Peripheral blood in heparin (see Note 3).

2. Ficoll-Paque.

3. $25 \mathrm{ml}$ stripettes.

4. $15 \mathrm{ml}$ and $50 \mathrm{ml}$ Falcon Tubes.

5. $3 \mathrm{ml}$ Pasteur pipettes.

6. Polypropelene FACS tubes.

7. Supplemented RPMI 1640 (with L-Glutamine and $\mathrm{NaHCO}_{3}$ ): RPMI, $10 \%$ fetal calf serum (FCS) and $0.01 \%$ penicillin-streptomycin.

8. Freezing media: $90 \%$ FCS and $10 \%$ DMSO.

9. Mr. Frosty ${ }^{\circledR}$ Freezing container.

10. Cryovials.

11. MACS Buffer: $1 \%$ FCS, 2mM EDTA in 1X PBS.

12. Trypan Blue for cell counts.

13. Haemocytometer.

14. OPTIONAL STEP: EasySep magnet and Human B cell enrichment kit for B cell isolation (StemCell: Used according to manufacturer's instructions) (see Note 4).

15. Fluorochrome conjugated anti-human CD19 (HIB19), CD24 (SN3) and CD38 (HB7) (see Note 5).

16. Live/Dead fixable Dead Cell stain kit.

17. DAPI $(0.05 \mu \mathrm{g} / \mathrm{ml}-0.1 \mu \mathrm{g} / \mathrm{ml})$.

18. Sort collection media: 1:1 mixture of MACS Buffer and FCS.

19. Cell sorter. 
20. Chinese hamster ovary $(\mathrm{CHO})$ cells expressing CD154 and untransfected control.

21. Supplemented DMEM containing $4500 \mu \mathrm{g} / \mathrm{ml}$ glucose, $110 \mu \mathrm{g} / \mathrm{ml}$ sodium pyruvate and $2 \mathrm{mM}$ L-glutamine: $5 \%$ FCS and $0.01 \%$ penicillinstreptomycin.

22. Tissue culture flasks: T25 or T75 flasks.

23. Irradiator.

24. PMA (50 ng/ml) and lonomycin (250 ng/ml).

25. Brefaldin A $(5 \mu \mathrm{g} / \mathrm{ml})$.

26. Intracellular fixation buffer (eBiosciences).

27. Permeabilization buffer (eBiosciences).

28. IL-10 (JES3-19F1) (see Note 5).

29. FACS Buffer: $0.5 \%$ FCS in $1 X$ PBS, $0.01 \% \mathrm{NaN}_{3}$.

30. Flow cytometer.

31. FlowJo Software or similar flow cytometry platform.

\section{Methods}

\subsection{Identification and isolation of Bregs in mice}

In this section, we describe the basic protocols needed to identify regulatory $B$ cells isolated from spleens dissected from mice.

\subsubsection{Isolation of mouse splenocytes}

1. Euthanize mice by $\mathrm{CO}_{2}$ inhalation, cervical dislocation or any other approved method. 
2. Dissect spleens from mice and put in $15 \mathrm{ml}$ falcon tubes containing ice cold RPMI containing $0.1 \%$ Penicillin/Streptomycin, and place directly on ice.

3. In a sterile hood, gently mash spleens through a $70 \mu \mathrm{M}$ cell strainer into a $50 \mathrm{ml}$ Falcon tube using the flat end of the plunger from a $5 \mathrm{ml}$ syringe. Wash filter with $15 \mathrm{ml}$ of RPMI. Centrifuge for $10 \mathrm{~min}, 4^{\circ} \mathrm{C}, 500 \times \mathrm{g}$ (see Note 6).

4. Discard supernatant, and re-suspend in $1 \mathrm{ml} / \mathrm{spleen}$ of red cell lysis buffer, leave for 2 min on ice. Following incubation with red cell lysis buffer, fill tube to the top with supplemented RPMI. Centrifuge for 10 $\min , 4^{\circ} \mathrm{C}, 500 \times \mathrm{g}$.

5. Re-suspend cells in 5-10ml of MACs buffer/spleen and count. Centrifuge for $10 \mathrm{~min}, 4^{\circ} \mathrm{C}, 500 \times \mathrm{g}$.

\subsubsection{Sorting and activation of $B$ cell subsets}

1. OPTIONAL STEP: Negatively isolate resting B cells using CD43 (ly-48) microbeads and LD columns according to manufacturer's instructions. Count cells. Centrifuge for $10 \mathrm{~min}, 4^{\circ} \mathrm{C}, 500 \times \mathrm{g}$ (see Note 7 ).

2. Resuspend cells at a concentration of $50 \times 10^{6}$ cells $/ \mathrm{ml}$. To identify T2MZP B cells stain cells with suggested monoclonal antibodies against CD19, CD21, CD23, and CD24 (staining concentrations in Note 2, see Fig. 1a for representative FACS plots). Concurrently, prepare single stain controls for compensation. Incubate cells with antibodies for a minimum of 20 min on ice. 
3. Wash twice by filling tube with ice-cold MACS buffer and centrifuging for $10 \mathrm{~min}, 4^{\circ} \mathrm{C}, 500 \times \mathrm{g}$. Re-suspend at $30-50 \times 10^{6}$ for cell sorter.

4. To prevent blockage of the cell sorter, remove clumps of cells by straining sample through a $40 \mu \mathrm{M}$ filter. Transfer cells to $5 \mathrm{ml}$ polystyrene FACS tubes for sorting.

5. Add DAPI (final concentration of $0.05 \mu \mathrm{g} / \mathrm{ml}-0.1 \mu \mathrm{g} / \mathrm{ml}$ ) to samples and DAPI single stained control.

6. Take sample to cell sort into B cell subsets. Use polypropelene tubes containing $1-2 \mathrm{mls}$ of sort collection medium to collect sorted $B$ cell subsets.

7. Collect sorted T2-MZP Bregs, and other subsets of interest, and centrifuge for $500 \times \mathrm{g}, 4^{\circ} \mathrm{C}$ for 10 mins.

8. Count cells, and prepare cells for downstream analysis (see Note 8).

\subsubsection{Detecting IL-10+ Bregs by flow cytometry using C57BL/6 mice}

1. For activation of $B$ cell subsets in vitro with agonistic anti-CD40, plate out the appropriate number of $B$ cells for subsequent assays $(\sim 250,000$ cells/well is adequate for detection of IL-10) in a final volume of $200 \mu \mathrm{l}$ and stimulate with agonistic anti-CD40 $(10 \mu \mathrm{g} / \mathrm{ml})$ in a sterile 96 -well cell culture plate.

2. Sorted B cell subsets are left in culture for $48 \mathrm{~h}$.

3. Collect cell culture supernatants after $43 \mathrm{~h}$ and store at $-80^{\circ} \mathrm{C}$ for subsequent use. 
4. Add $50 \mathrm{ng} / \mathrm{ml} \mathrm{PMA}, 500 \mathrm{ng} / \mathrm{ml}$ ionomycin and Monensin in supplemented RPMI to cells for the last $5 \mathrm{~h}$ of culture to a final volume of $200 \mu$ l.

5. Centrifuge plate at $500 \times \mathrm{g}, 4^{\circ} \mathrm{C}$ for $5 \mathrm{~min}$, discard supernatant, and wash cells twice by adding $200 \mu \mathrm{l} /$ well of 1 X PBS and centrifuging at $500 \times \mathrm{g}, 4^{\circ} \mathrm{C}$ for $5 \mathrm{~min}$.

6. Discard supernatant and resuspend cell pellets by gently vortexing plate.

7. Stain the cells with a fixable live/dead cell staining fluorescent dye for 20 min at $4^{\circ} \mathrm{C}$. Include a well for a single stain control for the dead cell stain. Centrifuge plate at $500 \times \mathrm{g}, 4^{\circ} \mathrm{C}$ for $5 \mathrm{~min}$, discard supernatant, and wash cells twice by adding $200 \mu \mathrm{l} /$ well of FACS buffer and centrifuging at $500 \times \mathrm{g}, 4^{\circ} \mathrm{C}$ for $5 \mathrm{~min}$. Discard supernatant.

8. Add $50 \mu \mathrm{l} /$ well of FACS buffer containing monoclonal antibodies against CD19 diluted to appropriate concentration (see Note 2) and incubate for 20 min at $4^{\circ} \mathrm{C}$ in the dark. Prepare single stain controls.

9. Centrifuge plate at $500 \times \mathrm{g}, 4^{\circ} \mathrm{C}$ for $5 \mathrm{~min}$, discard supernatant, and wash cells twice by adding $200 \mu \mathrm{l} /$ well of FACS buffer and centrifuging at $500 \times \mathrm{g}, 4^{\circ} \mathrm{C}$ for $5 \mathrm{~min}$.

10. Add $100 \mu \mathrm{l} /$ well intracellular fixation buffer (for detecting cytokines) to each well for 15 min at $4^{\circ} \mathrm{C}$ in the dark.

11. Permeabilize cells by washing twice with $200 \mu$ l of $1 \mathrm{X}$ permeabilization buffer and centrifuging at $500 \times \mathrm{g}, 4^{\circ} \mathrm{C}$ for $5 \mathrm{~min}$.

12. Incubate cells with $200 \mu$ l of $1 X$ permeabilization buffer for 20 mins at RT, then centrifuge at $500 \times \mathrm{g}, 4^{\circ} \mathrm{C}$ for $5 \mathrm{~min}$. 
13. Incubate the cells with $50 \mu$ of permeabilization buffer containing monoclonal antibodies against IL-10 diluted to appropriate concentration for $45 \mathrm{~min}$ at $4^{\circ} \mathrm{C}$ in the dark.

14. Wash cells twice with permeabilization buffer and once with FACs buffer, before resuspending in $200 \mu$ I FACs buffer.

15. Transfer the cells to polystyrene FACS tubes, acquire data, and analyze using FlowJo or similar analysis platform.

16. Identify IL-10 producing B cells.

\subsection{Identification and isolation of Bregs in humans}

In this section, we describe the basic protocols needed to identify regulatory $B$ cells isolated from the human peripheral blood mononuclear cells (PBMCs).

\subsubsection{Isolation of PBMCs by density gradient centrifugation}

1. In a sterile hood, transfer whole venous blood into $50 \mathrm{ml}$ falcon tubes, diluted 1:1 in serum free RPMI 1640 media.

2. Layer $33 \mathrm{ml}$ of diluted blood on $15 \mathrm{ml}$ Ficoll without mixing, and centrifuge the tubes at a speed of $800 \times \mathrm{g}$ at $21^{\circ} \mathrm{C}$ for $30 \mathrm{~min}$ with minimum acceleration and brake.

3. Carefully extract the PBMCs from the interface using a $2 \mathrm{ml}$ Pasteur pipette and dilute $1: 1$ with RPMI.

4. Wash the extracted PBMCs twice by topping up the $50 \mathrm{ml}$ tube with supplemented RPMI 1640 and centrifuging at $500 \times$ g, $4^{\circ} \mathrm{C}$ for $10 \mathrm{~min}$. Discard the supernatant. 
5. Resuspend cells in $0.5 \mathrm{ml}$ supplemented RPMI $/ \mathrm{ml}$ blood and count the cells using a haemocytometer

6. Centrifuge cells at $500 \times \mathrm{g}, 4^{\circ} \mathrm{C}$ for $10 \mathrm{~min}$, discard supernatant and resuspend in freezing media to a concentration of $10^{7} \mathrm{cells} / \mathrm{ml}$. Quickly transfer cells to cryogenic vials.

7. Freeze cryovials at $-80^{\circ} \mathrm{C}$ in a Nalgene ${ }^{\circledR}$ Mr. Frosty ${ }^{\circledR}$ Freezing container containing isopropyl alcohol (see Note 9), followed by storage in liquid nitrogen at $-196^{\circ} \mathrm{C}$ until subsequent use.

\subsubsection{Sorting and activation of $B$ cell subsets}

1. For isolation of B cell subsets, thaw frozen PBMCs in supplemented RPMI media and wash twice by filling tube with MACS buffer and centrifuging at $500 \times \mathrm{g}, 4^{\circ} \mathrm{C}$ for $5 \mathrm{~min}$.

2. OPTIONAL STEP: Negatively isolate B cells using Human B cell enrichment kit and EasySep Magnet according to manufacturer's instructions. Count cells. Centrifuge at $500 \times$ g, $4^{\circ} \mathrm{C}$ for $10 \mathrm{~min}$ (see Note 4).

3. Resuspend cells at a concentration of $5 \times 10^{7}$ cells $/ \mathrm{ml}$ in MACS buffer. To identify immature B cells, incubate the cells with monoclonal antibodies against CD19, CD24 and CD38 (used at $10 \mu \mathrm{l}$ per $5 \times 10^{7}$ cells) (staining concentrations in Note 5, see Fig. 2a for representative FACS plots). Concurrently, prepare single stain controls for compensation. Incubate cells with antibodies for a minimum of $20 \mathrm{~min}$ on ice. 
4. Wash cells twice by filling tube with MACS buffer and centrifuging at $500 \times \mathrm{g}, 4^{\circ} \mathrm{C}$ for $5 \mathrm{~min}$. Resuspend at a concentration of $30-50 \times 10^{6}$ cells/ml for cell sorter.

5. To prevent blockage of the cell sorter, remove clumps of cells by straining sample through a $40 \mu \mathrm{M}$ filter. Transfer cells to $5 \mathrm{ml}$ polystyrene FACS tubes for sorting.

6. Add DAPI (final concentration of $0.05 \mu \mathrm{g} / \mathrm{ml}-0.1 \mu \mathrm{g} / \mathrm{ml}$ ) to samples and prepare a single stained control.

7. Sort the PBMCs on a FACs sorter based on the expression of CD19, CD24 and CD38. B cell subsets are identified as immature

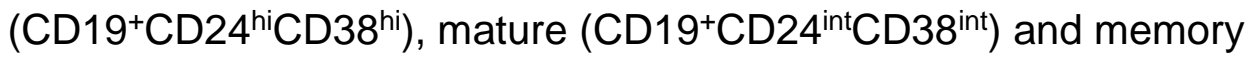
(CD19+CD24hi CD38-) B cells.

8. Collect the sorted B cell subsets in polypropylene tubes containing 1$2 \mathrm{ml}$ sort collection medium.

9. Prepare 96-well U-bottomed cell culture plates with CD154 (CD40L) transfected $\mathrm{CHO}$ cells as described in section 3.2.3. Estimate the number of $\mathrm{B}$ cells to be plated and plate out sufficient $\mathrm{CHO}$ cells for a 1:10 ratio of $\mathrm{CHO}: \mathrm{B}$ cells. Leave $\mathrm{CHO}$ cells for at least two hours in an incubator at $37^{\circ} \mathrm{C}$ to allow the cells to adhere to the plate.

10. Wash sorted B cell subsets twice by filling collection tubes with supplemented RPMI and centrifuging at $500 \times \mathrm{g}, 4^{\circ} \mathrm{C}$ for $10 \mathrm{~min}$.

11. Count the number of B cells in each sorted subset and add cells to wells containing CD154 (CD40L) transfected CHO cells (or control CHO cells). $250,000 \mathrm{~B}$ cells/well is sufficient for detecting IL-10 by flow 
cytometry (see Note 10). The final volume in the wells should be $200 \mu$ l. Handling $\mathrm{CHO}$ cells in explained in section 3.2.3.

\subsubsection{Working with $\mathrm{CHO}$ cells}

1. Thaw aliquot of CD154-transfected and untransfected $\mathrm{CHO}$ cells in pre-warmed supplemented DMEM media in a $50 \mathrm{ml}$ tube.

2. Wash twice by filling tube with DMEM and centrifuging at $500 \times \mathrm{g}, 4^{\circ} \mathrm{C}$ for $5 \mathrm{~min}$.

3. Resuspend cells in $20 \mathrm{ml}$ of supplemented DMEM media and seed in a T25 or T75 flask for 3-4 days or until 90\% confluent (see Note 11).

4. Irradiate $\mathrm{CHO}$ cells- dose of 70 Gray (see Note 12).

5. Remove media from the T25 flasks and wash twice with $1 \mathrm{X}$ sterile PBS. Rinse around the inside of the flask a few times each wash.

6. Add $1.5 \mathrm{ml}$ Trypsin-EDTA to detach the adherent confluent $\mathrm{CHO}$ cells (see Note 13).

7. Incubate at $37^{\circ} \mathrm{C}$ for $3-4 \mathrm{~min}$. Tap the flask to check whether the cells have detached.

8. Once detached, add $10 \mathrm{ml}$ of supplemented DMEM to inhibit enzymatic reaction. Transfer cells from flask to a $50 \mathrm{ml}$ tube.

9. Wash twice by filling tube with supplemented RPMI and centrifuging at $500 \times \mathrm{g}, 4^{\circ} \mathrm{C}$ for $5 \mathrm{~min}$.

10. Count cells and plate for culture with B cells (step 9 of section 3.2.2). 
17. The sorted $\mathrm{B}$ cell subsets are in culture with $\mathrm{CHO}$ cells for $72 \mathrm{~h}$ (Section 3.2.2).

18. Collect cell culture supernatants after $67 \mathrm{~h}$ and store at $-80^{\circ} \mathrm{C}$ for subsequent use.

19. Add 50ng/ml PMA, 250ng/ml ionomycin and brefaldin A in supplemented RPMI to cells in culture for the last $5 \mathrm{~h}$ to a final volume of $200 \mu \mathrm{l}$.

20. Centrifuge plate at $500 \times \mathrm{g}, 4^{\circ} \mathrm{C}$ for $5 \mathrm{~min}$, and discard supernatant, and wash cells twice by adding $200 \mu \mathrm{l} /$ well 1 X PBS and centrifuging at $500 \times \mathrm{g}, 4^{\circ} \mathrm{C}$ for $5 \mathrm{~min}$.

21. Discard the supernatants and resuspend cell pellets by gently vortexing the plate.

22. Stain the cells with a fixable live/dead cell staining fluorescent dye for 20 min at $4^{\circ} \mathrm{C}$. Include a well for a single stain control for the dead cell stain. Centrifuge plate at $500 \times \mathrm{g}, 4^{\circ} \mathrm{C}$ for $5 \mathrm{~min}$, discard supernatant, and wash cells twice by adding $200 \mu \mathrm{l} /$ well of 1 X FACS buffer and centrifuging at $500 \times \mathrm{g}, 4^{\circ} \mathrm{C}$ for $5 \mathrm{~min}$. Discard supernatant.

12. Add $50 \mu \mathrm{l} /$ well of FACS buffer containing monoclonal antibodies against CD19 diluted to appropriate concentration and incubate for $20 \mathrm{~min}$ at $4^{\circ} \mathrm{C}$ in the dark. Prepare single stain controls.

13. Centrifuge plate at $500 \times \mathrm{g}, 4^{\circ} \mathrm{C}$ for $5 \mathrm{~min}$, discard supernatant, and wash cells twice by adding $200 \mu \mathrm{l} /$ well of FACS buffer and centrifuging at $500 \times \mathrm{g}, 4^{\circ} \mathrm{C}$ for $5 \mathrm{~min}$.

14. Add $100 \mu \mathrm{l} /$ well intracellular fixation buffer (for detecting cytokines) to each well for $15 \min$ at $4^{\circ} \mathrm{C}$ in the dark. 
15. Wash once with FACs buffer by adding $200 \mu \mathrm{l} /$ well of FACS buffer and centrifuging at $500 \times \mathrm{g}, 4^{\circ} \mathrm{C}$ for $5 \mathrm{~min}$.

16. Permeabilize cells by washing twice with $200 \mu$ l of $1 \mathrm{X}$ permeabilization buffer and centrifuging at $500 \times \mathrm{g}, 4^{\circ} \mathrm{C}$ for $5 \mathrm{~min}$.

17. Incubate the cells with $50 \mu$ l of permeabilization buffer containing monoclonal antibodies against IL-10 diluted to appropriate concentration for 45 min at $4^{\circ} \mathrm{C}$ in the dark.

18. Wash cells twice with permeabilization buffer and once with FACs buffer, before resuspending in $200 \mu$ I FACs buffer.

23. Transfer the cells to polystyrene FACs tubes, acquire data and analyze using FlowJo or similar analysis platform.

19. Identify regulatory $B$ cells as IL-10+CD19+ $B$ cells within the immature $B$ cells (see Note 14). In addition to IL-10 production, regulatory function of $B$ cell subsets can also we assessed by suppression assay $[6,8]$.

\section{Notes}

1. You can use mice of any strain, sex or age for these experiments. However, the number of Bregs changes over age, and varies between strains, and the representative gating we have provided is for C57BL/6 8-12 week-old female mice. It is also important to note that Bregs are rare in naïve mice, and expanded following remission from autoimmune disease. Given these factors, we recommend using 8-12 week old mice that are in remission from autoimmune disease for the 
isolation of murine Bregs. For experiments where cells will be collected to assess the ability of Bregs to suppress pro-inflammatory responses in vivo or in vitro, samples can be pooled to achieve sufficient numbers of Bregs for assays. Furthermore, the use of IL-10eGFP reporter mice allows ex vivo identification of IL-10 by flow cytometry without the need for in vitro stimulation.

2. These suggested clones of anti-CD19, anti-CD21, anti-CD23, and antiCD24 antibodies are used at staining concentrations of $0.8 \mu \mathrm{g} / \mathrm{ml}$, and anti-IL-10 is used at a staining concentration of $4 \mu \mathrm{g} / \mathrm{ml}$. Other clones can be used but they would need to be optimized.

3. Whole venous blood must be collected in sodium heparin-coated tubes or sterile $50 \mathrm{ml}$ centrifuge tubes containing $2 \mathrm{IU} / \mathrm{mL}$ heparin.

4. This enrichment of $B$ cells using a negative selection kit is to shorten the time it takes to sort the B cell subsets by flow cytometry.

5. These clones of anti-CD19, anti-CD24 and anti-CD38 antibodies are used at a staining concentration of $2 \mu \mathrm{g} / \mathrm{ml}$, and the noted clone of antiIL-10 is used at $4 \mu \mathrm{g} / \mathrm{ml}$. Other clones would need to be optimized prior to use.

6. Other techniques to isolate splenocytes can be used. However as we usually work with large numbers of mice, we find this technique the most convenient and the least variable.

7. As the purpose of this step is to enrich for B cells in order to make the cell sort run faster than if B cells were sorted directly from splenocytes, several different B cell enrichment kits can be used, and as $100 \%$ purity is not necessary, reagents can be diluted further than 
recommended. However, we would recommend using kits that negatively select for $B$ cells.

8. At this point, cells can also be used to assess their ability to suppress pro-inflammatory response both in vivo and in vitro. Assessment of disease suppression by Bregs in vivo remains the gold standard for their identification and analysis of their function in mice, as IL-10 production does not correlate with the suppressive capacity of B cells in all models of inflammation. In the context of arthritis, we have described the protocols necessary to assess Breg suppression in vivo in a previous edition of molecular methods in molecular biology [9].

9. This is to ensure freezing at a controlled rate of $-1^{\circ} \mathrm{C} /$ minute, resulting in improved viability of PBMCs.

10.1 $\mathrm{g} / \mathrm{ml}$ MegaCD40L from Enzo LifeSciences can be used as an alternative to $\mathrm{CHO}-\mathrm{CD} 40 \mathrm{~L}$ cells to stimulate B cells. Although the induction of Bregs is not equivalent, it is comparable.

11. The $\mathrm{CHO}$ cells must be cultured $3-4$ days prior to setting up culture with isolated B cell subsets.

12. In order to expand and aliquot $\mathrm{CHO}$ cells for future use, do not irradiate the cells (skip to step 4). The cells should not have more than 3 passages as they lose the expression of CD40L. Once cells have been detached, wash twice with supplemented DMEM media and freeze cells in 2-5 million cells/ml aliquots in freezing media.

13. The trypsin-EDTA solution must be pre-warmed in a water bath at $37^{\circ} \mathrm{C}$ for detachment of adherent $\mathrm{CHO}$ cells. 
14. The presence of $\mathrm{CHO}$ cells does not affect the detection of IL-10producing Bregs. Majority of the $\mathrm{CHO}$ cells will be attached to the well, and those detached can be discriminated from lymphocytes on the FSC-SSC plot.

\section{Acknowledgements}

We would like to thank Dr. Paul Blair for his constructive criticism of the manuscript. Madhvi Menon is funded by a Wellcome Trust PhD studentship (090406/Z/09/Z). Elizabeth C. Rosser was funded by an Arthritis Research UK PhD studentship (MP/19314).

\section{References}

1. Mauri C, Bosma A (2012) Immune regulatory function of B cells. Annu Rev Immunol 30:221-241. doi:10.1146/annurev-immunol-020711-074934

2. Evans JG, Chavez-Rueda KA, Eddaoudi A, Meyer-Bahlburg A, Rawlings DJ, Ehrenstein MR, Mauri C (2007) Novel suppressive function of transitional 2 B cells in experimental arthritis. J Immunol 178 (12):7868-7878

3. Miles K, Heaney J, Sibinska Z, Salter D, Savill J, Gray D, Gray M (2012) A tolerogenic role for Toll-like receptor 9 is revealed by B-cell interaction with DNA complexes expressed on apoptotic cells. Proc Natl Acad Sci U S A 109 (3):887-892. doi:10.1073/pnas.1109173109

4. Ding Q, Yeung M, Camirand G, Zeng Q, Akiba H, Yagita H, Chalasani G, Sayegh MH, Najafian N, Rothstein DM (2011) Regulatory B cells are identified by expression of TIM-1 and can be induced through TIM-1 ligation to promote tolerance in mice. J Clin Invest 121 (9):3645-3656. doi:10.1172/JCl46274 5. Yanaba K, Bouaziz JD, Haas KM, Poe JC, Fujimoto M, Tedder TF (2008) A regulatory $B$ cell subset with a unique CD1dhiCD5+ phenotype controls $T$ celldependent inflammatory responses. Immunity 28 (5):639-650. doi:10.1016/j.immuni.2008.03.017

6. Blair PA, Norena LY, Flores-Borja F, Rawlings DJ, Isenberg DA, Ehrenstein MR, Mauri C (2010) CD19(+)CD24(hi)CD38(hi) B cells exhibit regulatory capacity in healthy individuals but are functionally impaired in systemic Lupus Erythematosus patients. Immunity 32 (1):129-140. doi:10.1016/j.immuni.2009.11.009 
7. Iwata Y, Matsushita T, Horikawa M, Dilillo DJ, Yanaba K, Venturi GM, Szabolcs PM, Bernstein SH, Magro CM, Williams AD, Hall RP, St Clair EW, Tedder TF (2011) Characterization of a rare IL-10-competent B-cell subset in humans that parallels mouse regulatory B10 cells. Blood 117 (2):530-541. doi:10.1182/blood-2010-07-294249

8. Flores-Borja F, Bosma A, Ng D, Reddy V, Ehrenstein MR, Isenberg DA, Mauri C (2013) CD19+CD24hiCD38hi B cells maintain regulatory T cells while limiting TH1 and TH17 differentiation. Sci Transl Med 5 (173):173ra123. doi:10.1126/scitranslmed.3005407

9. Rosser EC, Mauri C (2014) Regulatory B cells in experimental mouse models of arthritis. Methods Mol Biol 1190:183-194. doi:10.1007/978-1-49391161-5_13

\section{Figure legends}

Figure 1: Gating strategy Breg isolation from mouse splenocytes. Isolated splenic B Cells from mice were stained with monoclonal antibodies against CD19, CD21, CD23, and CD24 for FACS sorting. a) Representative flow cytometry dot plots showing gating strategy for purification of $B$ cell subsets. Highlighted gate in red shows population of interest, in this case T2MZP.

Figure 2: Gating strategy Breg isolation from human PBMCs. Isolated human PBMCs were stained with monoclonal antibodies against CD19, CD24, and CD38 for FACS sorting. a) Representative flow cytometry dot plots showing gating strategy for purification of B cell subsets. Highlighted gate in red shows population of interest, in this case immature B cells. 